http://dx.doi.org/10.11646/phytotaxa.163.2.5

\title{
Two new Eugenia species (Myrtaceae) from the Brazilian Atlantic forest
}

\author{
AUGUSTO GIARETTA $^{1^{*}}$ \& CLAUDIO NICOLETTI DE FRAGA ${ }^{2}$ \\ ${ }^{I}$ Instituto de Pesquisas Jardim Botânico do Rio de Janeiro, Escola Nacional de Botânica Tropical, Rua Pacheco Leão, 2040, $22.460-$ \\ 030, Jardim Botânico, Rio de Janeiro, Brazil. \\ ${ }^{2}$ Instituto de Pesquisas Jardim Botânico do Rio de Janeiro, Rua Pacheco Leão, 915, 22.460-030, Jardim Botânico, Rio de Janeiro, \\ Brazil. \\ "Corresponding author: (augustogiaretta@gmail.com)
}

\begin{abstract}
Two new species of Eugenia (Myrtaceae), endemic to the Atlantic forest in the state of Espírito Santo, Brazil, are described. Eugenia amorimii has fruits with brown mealy indumentum and is similar to E. multicostata, while Eugenia sobraliana has a characteristic pedicels exfoliating longitudinally after anthesis and is similar to E. sessiliflora. The new species are restricted to single localities in the central and northwestern regions of Espírito Santo. According to the criteria of the IUCN Red List of endangered plant species both species should be considered as "Vulnerable".
\end{abstract}

Key words: Brazil, endemism, Espírito Santo, new species, taxonomy

\section{Introduction}

One of the original centers of diversification of the Myrtaceae is the Atlantic forest of the tropical to temperate southeastern South America (Wilson et al. 2001), one of the largest rainforests in the Americas. Most of its original cover is found in Brazil, with 684 species, around 75\% of which endemic to this domain (Sobral et al. 2013). Eugenia Linnaeus (1753: 470) is one of the largest genera of the Brazilian Myrtaceae (Landrum \& Kawasaki 1997) and is well-represented in the floristic inventories of Espírito Santo (Jesus \& Rolim 2005, Saiter et al. 2011, Giaretta et al. 2013).

The remaining forest cover in Espírito Santo is about 8\% of the original Atlantic forest and only 3\% of its state territory is found in protected areas (Lani et al. 2008). They comprise about 48,000 ha, with the Protected Environmental Area of Pedra do Elefante and the Biological Reserve of Duas Bocas of particular importance. Scarce botanical collections in these protected areas called for the intensification of survey efforts by the team working on the project "Vascular plant diversity and the conservation status of endemic species of three protected areas of the montane Atlantic forest in Espírito Santo", where both of the new species were collected.

\section{Material and Methods}

Morphological data were obtained through the study of herbarium specimens, as well as material collected during field work, with the descriptions, key and illustrations based on both fresh and dried fertile material. Voucher specimens were dried and pressed according to Fidalgo \& Bononi (1984) and deposited at RB, with duplicates distributed to BHCB, CEPEC, MBML, RB and UPCB.

Data on the distribution of the new species is presented mapped with elevations, state limits, and vegetation remnants taken from satellite images. The map was made using DIVA-GIS program, version 5.2 (Hijmans et al. 2005); satellite images were downloaded from Google Earth. 
Distribution and habitat:-Eugenia sobraliana is known so far from only two collections in the Environmental Protection Area of Pedra do Elefante, in the municipality of Nova Venécia, Espírito Santo (Fig. 3) and is seemingly restricted to inselbergs covered in dry seasonal forests, at elevations of c. 150 to $360 \mathrm{~m}$ elev. The region is characterized by granitic and gneissic inselbergs that are frequently dome-shaped and rise more or less abruptly above the surrounding landscape and delimited by the border of the tropical semideciduous forest. The inselbergs of southeastern Brazil have been recognized as one of the three top hotspots of the inselberg plant diversity, by their species richness and the high level of endemism (Porembski 2007). Several endemic species of other plant families have been recently described for these dry seasonal forest remnants (Versieux \& Wanderley 2010; Leme et al. 2010; Goldenberg et al. 2012).

Conservation:- This species is endemic to just one locality, with populations of few and scattered individuals in an area of less than $20 \mathrm{~km}^{2}$. It is thus prone to the effects of stochastic events, and its continued existence can't be assured. Although this locality lies in a protected area, it has open boundaries with livestock farms and their frequently undisciplined use of natural resources. We therefore include this species under the category VU D2 of the IUCN Red List (IUCN 2013) of endangered plant species.

Paratype:-BRAZIL. Espírito Santo: Nova Venécia, Área de Proteção Ambiental da Pedra do Elefante, Trilha Principal na Mata da Fazenda Santa Rita, Floresta Estacional Semidecidual, Elev. 154 m, 16 Jul. 2008 (fl.), A.M. Amorim et al. 7522 (BHCB, CEPEC, MBML, RB!, UPCB).

Affinities:-Eugenia sobraliana is close to Eugenia sessilifolia de Candolle (1828: 263), from which it differs by the morphological characters presented in the following key:

1. Leaves elliptic, base truncate or subcordate; inflorescence terminal on an auxotelic axis producing vegetative shoots with adult leaves after anthesis, flowers 2-6; pedicels not exfoliating...... Eugenia sessilifolia

1'. Leaves ovate, base cordate to subcordate; inflorescence axillary, fasciculiform, with 2-4 flowers; pedicels exfoliating after anthesis Eugenia sobraliana

\section{Acknowledgments}

We thank André M. Amorim, André Paviotti Fontana, Ludovic Kollmann, Paulo Labiak, Rafaela C. Forzza and Renato Goldenberg for their company and help during the fieldwork. The first author was supported by a grant from the Coordenação de Aperfeiçoamento de Pessoal de Nível Superior (CAPES); the second author by a grant from the project "Diversidade da flora vascular e status de conservação das espécies endêmicas em três Unidades de Conservação de floresta atlântica montana no Estado do Espírito Santo", sponsored by the Fundação O Boticário de Proteção à Natureza (Proc. 0756-20072). We also express our gratitude to the Instituto Estadual de Meio Ambiente - IEMA (Espírito Santo) for the support and permission to collect in the "Reserva Biológica de Duas Bocas" and "Área de Proteção Ambiental da Pedra do Elefante"; and Alex Popovkin for the English language review and suggestions for this manuscript.

\section{References}

Alves, M.V., Thomas, W.W. \& Wanderley, M.G.L. (2002) New species of Hypolytrum Rich. (Cyperaceae) from the Neotropics. Brittonia 54: 124-135. http://dx.doi.org/10.1663/0007-196x(2002)054[0124:nsohrc]2.0.co;2

Berg, O.C. (1857-1859) Myrtaceae. In: Martius, K.F.P. von (org.) Flora Brasiliensis 14(1): 1-656.

Camargo, E.A. \& Goldenberg, R. (2011) Two new species of Leandra from Espírito Santo, Brazil. Brittonia 63: $220-226$.

Candolle, A.P. de (1828) Myrtaceae. In: Prodromus Systematis Universalis Regni Vegetabilis 3: 263. http://dx.doi.org/10.5962/bhl.title.286

Fiaschi, P. \& Pirani, J.R. (2005) Four new species of Schefflera (Araliaceae) from Espírito Santo State, Brazil. Kew Bulletin 60: 77-85.

Fraga, C.N. \& Saavedra, M.M. (2006) Three new species of Elvasia (Ochnaceae) from the Brazilian Atlantic Forest, with an emended key for subgenus Hostmannia. Novon 16: 483-489. http://dx.doi.org/10.3417/1055-3177(2006)16[483:tnsoeo]2.0.co;2

Giaretta, A., Menezes, L.F.T. \& Pereira, O.J. (2013) Structure and floristic pattern of coastal dunes in southeastern Brazil. Acta Botanica Brasilica 27(1): 87-107. 
http://dx.doi.org/10.1590/s0102-33062013000100011

Goldenberg, R., Fraga, C.N., Fontana, A.P., Nicolas, A.N. \& Michelangeli, $\quad$ F.A. (2012) Taxonomy and phylogeny of Merianthera (Melastomataceae). Taxon 61(5): 1040-1056.

IUCN (2013) Guidelines for Using the IUCN Red List Categories and Criteria. Version 10.1. Prepared by the Standards and Petitions Subcommittee. Available from: http://www.iucnredlist.org/documents/RedListGuidelines.pdf (accessed: 9 February 2014).

Jesus, R.M. \& Rolim, S.G. (2005) Fitossociologia da Mata Atlântica de Tabuleiro. Boletim Técnico da Sociedade de Investigações Florestais 19: 1-149.

Kollmann, L.J.C. \& Peixoto, A.L. (2012) Begonia fragae L. Kollmann \& Peixoto and Begonia wasshauseniana L. Kollmann \& Peixoto (Begoniaceae), two new species from the state of Espírito Santo, Brazil. Candollea 67: 59-64.

Landrum, L.R. \& Kawasaki, M.L. (1997) The genera of Myrtaceae in Brazil - an illustrated synoptic treatment and identification keys. Brittonia 49: 508-536.

http://dx.doi.org/10.2307/2807742

Lani, J.L., Resende, M., Rezende, S.B. \& Feitoza, L.R. (2008) Atlas de Ecossistemas do Espírito Santo. SEMA, Editora GSA, Viçosa, $504 \mathrm{pp}$.

Legrand, C.D. (1961) Mirtaceas del estado de Santa Catarina (Brasil). Sellowia 13: 309.

Leme, E.M.C., Fraga, C.N., Kollmann, L.J.C., Brown, G.K., Till, W., Ribeiro, O.B.C., Machado, M.C., Monteiro, F.J.S. \& Fontana, A.P. (2010) Miscellaneous new species in the Brazilian Bromeliaceae. Rodriguésia 61(1): $21-67$.

Linné, Carl von (1753) Myrtaceae. In: Species Plantarum (1): 470.

Porembski, S. (2007) Tropical inselbergs: habitat types, adaptive strategies and diversity patterns. Brazilian Journal of Botany 30: 579-586. http://dx.doi.org/10.1590/s0100-84042007000400004

Saiter, F.Z., Guilherme, F.A.G, Thomaz, L.D. \& Wendt, T. (2011) Tree changes in a mature rainforest with high diversity and endemism on the Brazilian coast. Biodiversity and Conservation 20: 1921-1949. http://dx.doi.org/10.1007/s10531-011-0067-3

Sobral, M., Proença, C., Souza, M., Mazine, F. \& Lucas, E. (2013) Myrtaceae. In: Lista de Espécies da Flora do Brasil. Jardim Botânico do Rio de Janeiro. Available from: http://floradobrasil.jbrj.gov.br/jabot/floradobrasil/FB171 (accessed: 17 March 2013).

Sousa, G.M. (2004) Revisão taxonômica de Aechmea Ruiz \& Pav. subg. Chevaliera (Gaudich. ex Beer) Baker BromelioideaeBromeliaceae. PhD thesis, Instituto de Biociências da Universidade de São Paulo, São Paulo, 179 pp.

Versieux, L.M. \& Wanderley, M.G.L. (2010) Delimitation of the Alcantarea extensa complex (Bromeliaceae) and a new species from Espírito Santo, Brazil. Rodriguésia 61(3): 421-429.

Wilson, P.G., O’Brien, M.M., Gadek, P.A. \& Quinn, C.J. (2001) Myrtaceae revisited: a reassessment of infrafamilial groups. American Journal of Botany 88: 2013-2025.

http://dx.doi.org/10.2307/3558428 